\title{
The family Opisidae (Crustacea: Amphipoda: Lysianassoidea) in Australasian waters
}

\author{
H.E. STODDART \& J.K. LOWRY \\ Crustacea Section, Australian Museum, 6 College Street, Sydney, New South Wales, 2010, Australia. \\ E-mail: helen.stoddart@austmus.gov.au; jim.lowry@austmus.gov.au
}

\begin{abstract}
The lysianassoid amphipod family Opisidae is reported from Australian waters for the first time. Five new species in three genera are described: Normanion hipposideros sp. nov., N. whoi sp. nov., Podoprionella bulla sp. nov., Podoprionides akantha sp. nov., P. moonamoona sp. nov.
\end{abstract}

Key words: Crustacea, Amphipoda, Opisidae, Australia, taxonomy, new species, Normanion, Podoprionella, Podoprionides

\section{Introduction}

The Opisidae is a small family of four genera and 17 species known mainly from the North Pacific Ocean, North Atlantic Ocean and Mediterranean Sea. Only two species, Podoprionides incerta Walker, 1906 from the Antarctic and Podoprionella dagadugaban Lowry \& Stoddart, 1995, from Papua New Guinea, have been reported previously outside these areas. In this paper we report opisids from Australia for the first time. Three of the four known genera are now recorded from the Australian and Papua New Guinean area.

The genus Normanion has previously been recorded from the eastern North Atlantic Ocean and the Mediterranean Sea. New records from south-eastern Australia and southern Papua New Guinea significantly extend the distribution of the genus and place it in the southern hemisphere for the first time. Podoprionella was also known only from the eastern North Atlantic Ocean and Mediterranean Sea until it was recorded recently from Papua New Guinea (Lowry \& Stoddart 1995). In this paper we record it from Australia for the first time. The third genus, Podoprionides, was considered until now as an Antarctic endemic. We also record it from Australia for the first time. The only opisid genus not known from Australian waters is Opisa, which is widespread throughout the boreal North Atlantic and North Pacific (Hurley 1963; Lincoln 1979; Bousfield 1987)

It appears that members of the Opisidae are more widespread than previous records would indicate and are probably living throughout the Indo-Pacific area. However, records are relatively rare and the animals may be difficult to collect. During the intensive collecting program on the Great Barrier Reef in 2005 and 2006 (Lowry \& Myers 2009) no opisids were collected, yet species are recorded from north and south of the Reef. Neither were any collected in the many baited traps of the SEAS project along the whole east coast of Australia (Lowry \& Smith 2003).

Many opisids are regarded as epi-parasites of fish (Vader \& Romppainen 1985; Bousfield 1987). The evidence for this is both direct and indirect. Normanion amblyops Sars, 1895, N. quadrimanus (Bate \& Westwood, 1868), N. sarsi Diviacco \& Vader, 1988, Opisa eschrichtii (Krøyer, 1842), O. odontochela Bousfield, 1987 and $O$. tridentata Hurley, 1963, have all been recorded from living and dead fish skins. Normanion abyssi Chevreux, 1903 and Podoprionella dagadugaban were originally taken in baited traps. In 
these cases it is likely that the amphipods were attracted to the smell of the fish in order to attach and not to scavenge, because opisids do not have the mouthpart structure of a scavenger. No other species of Podoprionella and no species of Podoprionides is a known associate of fish. Podoprionides moonamoona has been found repeatedly as an epibiont on ascidians. There could be two different lifestyles occurring in this family.

\section{Materials and methods}

The descriptions were generated from a DELTA database (Dallwitz 2005) to the opisid species of the world. Material is lodged in the Australian Museum, Sydney (AM) and Museum Victoria, Melbourne (MV). Standard abbreviations on the plates are: A, antenna; C, coxa; E, epistome; EP, epimeron; G, gnathopod; H, head; IP, inner plate; 1, left; MD, mandible; MP, maxilliped; MX, maxilla; P, pereopod; r, right; T, telson; U, uropod.

\section{Opisidae Lowry \& Stoddart, 1995}

The family diagnosis given by Lowry \& Stoddart (1995: 139) should be corrected to: Mandible molar present or absent.

\section{Normanion Bonnier, 1893}

Remarks. The genus has been revised by Kilgallen et al. (2006). Their generic diagnosis needs to be modified to: Gnathopod 1 subchelate or weakly chelate. This will accommodate Normanion whoi.

With the two new species described below the genus now contains seven species: Normanion abyssi Chevreux, 1903; N. amblyops Sars, 1895; N. chevreuxi Diviacco \& Vader, 1988; N. hipposideros sp. nov.; . quadrimanus (Bate \& Westwood, 1868); N. ruffoi Diviacco \& Vader, 1988; N. whoi sp. nov.

\section{Key to species of Normanion}

(modified from Kilgallen et al., 2006)

1. Maxilliped palp 4-articulate, extending beyond tip of inner plate; gnathopod 1 propodus broader than long ........... 2

- Maxilliped palp 3-articulate, reaching only to tip of inner plate; gnathopod 1 propodus subequal in length and

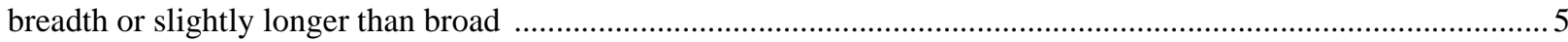

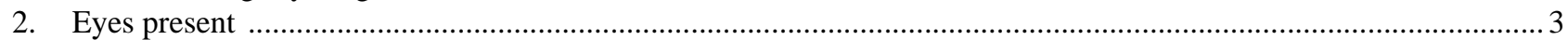

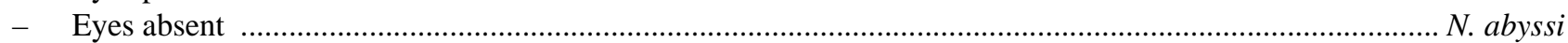

3. Maxilliped palp extending beyond outer plate; gnathopod 2 carpus about $2 \mathrm{x}$ length of propodus ............. amblyops

- Maxilliped palp not extending beyond outer plate; gnathopod 2 carpus about $1.5 \mathrm{x}$ length of propodus .................. 4

4. Some of maxilla 1 outer plate setal teeth with 2 rows of cusps; gnathopod 1 propodus not produced posterodistally, gnathopod subchelate. N. hipposideros

- Maxilla 1 outer plate setal teeth with 1 row of cusps; gnathopod 1 propodus produced posterodistally, gnathopod weakly chelate N. whoi

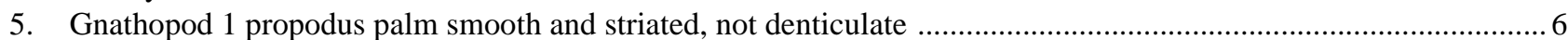

- Gnathopod 1 propodus palm distinctly denticulate ....................................................................... chevreuxi

6. Uropod 3 rami subequal; telson entire …..................................................................................

- Uropod 3 rami distinctly unequal; telson slightly emarginate ..................................................... N. quadrimanus 


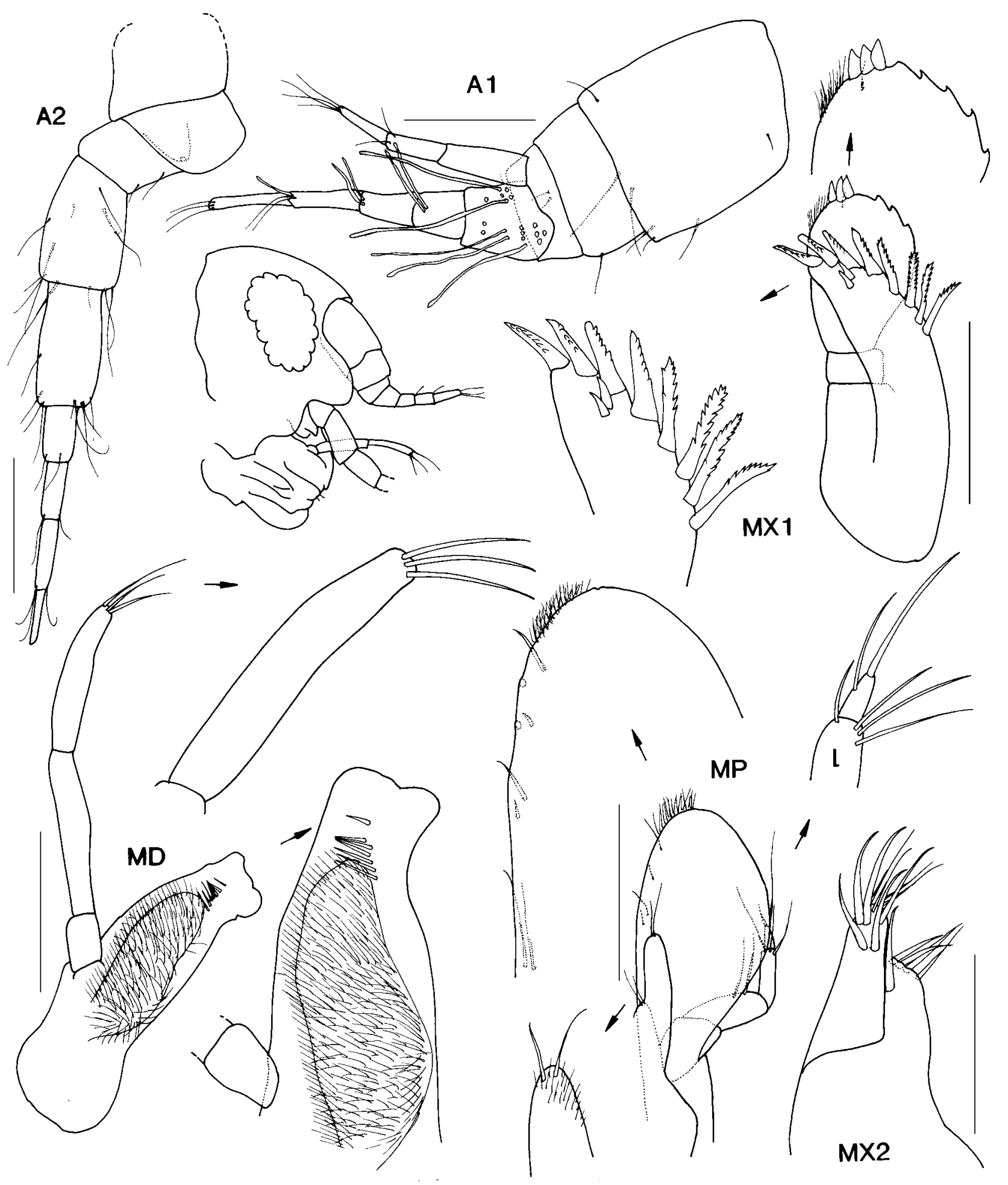

FIGURE 1. Normanion hipposideros sp. nov. Holotype female, AM P.69040. Scales represent $0.1 \mathrm{~mm}$.

\section{Normanion hipposideros sp. nov.}

(Figs 1,2)

Type material. HOLOTYPE, female, 2.5 mm, AM P.69040, Horseshoe Reef, Horsehoe Reef, Bootless Inlet, Papua New Guinea, $9^{\circ} 30.5^{\prime} \mathrm{S} 147^{\circ} 15.5^{\prime} \mathrm{E}, 12-15 \mathrm{~m}$, coral rubble from reef front slope, 29 October 1980, J.K. Lowry, stn PNG-32. 


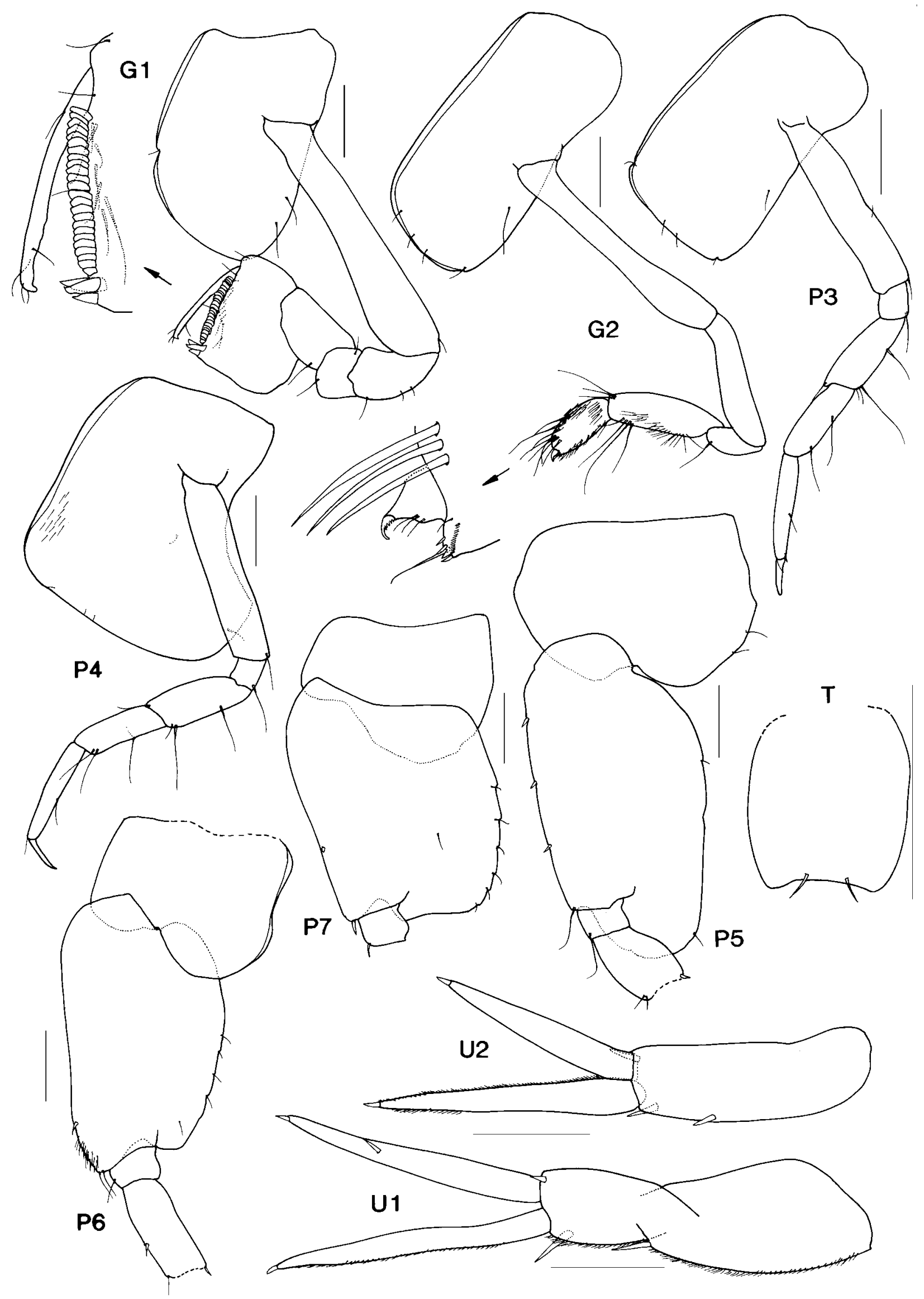

FIGURE 2. Normanion hipposideros sp. nov. Holotype female, AM P.69040. Scales represent $0.1 \mathrm{~mm}$. 
Type locality. Horsehoe Reef, Bootless Inlet, Papua New Guinea, 9 $9^{\circ} 30.5^{\prime} \mathrm{S} 147^{\circ} 15.5^{\prime} \mathrm{E}, 12-15 \mathrm{~m}$ depth.

Etymology. The species name is the Greek word for a horseshoe, a reference to the type locality.

Diagnostic description. Antenna 1 callynophore present. Eyes present. Mouthpart bundle subconical. Mandible left and right incisor with slightly convex margin, smooth; lacinia mobilis absent; molar present, setose; palp attached proximally, articles 2 and 3 subequal. Maxilla 1 outer plate with 10 setal teeth in an 8/2 crown arrangement, some of outer row with cusps in 2 rows; palp apical margin serrate, with apical robust setae. Maxilliped palp 4-articulate, article 4 vestigial. Gnathopod 1 subchelate; ischium long; carpus posterior margin not produced, curved; propodus subquadrate, proximal margin produced into strong posteroproximal lobe, palm serrate, posterodistal corner not produced, with 3 robust setae. Gnathopod 2 minutely chelate; carpus longer than propodus (about 1.5x); palm obtuse. Pereopod 4 coxa posteroproximal excavation large. Pereopods 5-7 basis with smooth posterior margin; [dactylus not known]. Epimeron 3 posterior margin smooth, posteroventral corner broadly rounded. [Uropod 3 unknown.] Telson about as long as broad, entire, distally emarginate, without dorsal robust setae.

Male not known.

Remarks. Unfortunately the specimen lacks the distal articles of pereopods 5-7 and uropod 3. Normanion hipposideros has the unusual character of having two rows of cusps on some of the outer row of setal teeth on the maxilla 1 outer plate, a character which also occurs in Podoprionella dagadugaban Lowry \& Stoddart, 1995. Although the status of uropod 3 is not known for $N$. hipposideros the presence of a large setose molar excludes the species from the genus Podoprionella. See also remarks under $N$. whoi.

Distribution. Southern Papua New Guinea; $12-15$ m depth.

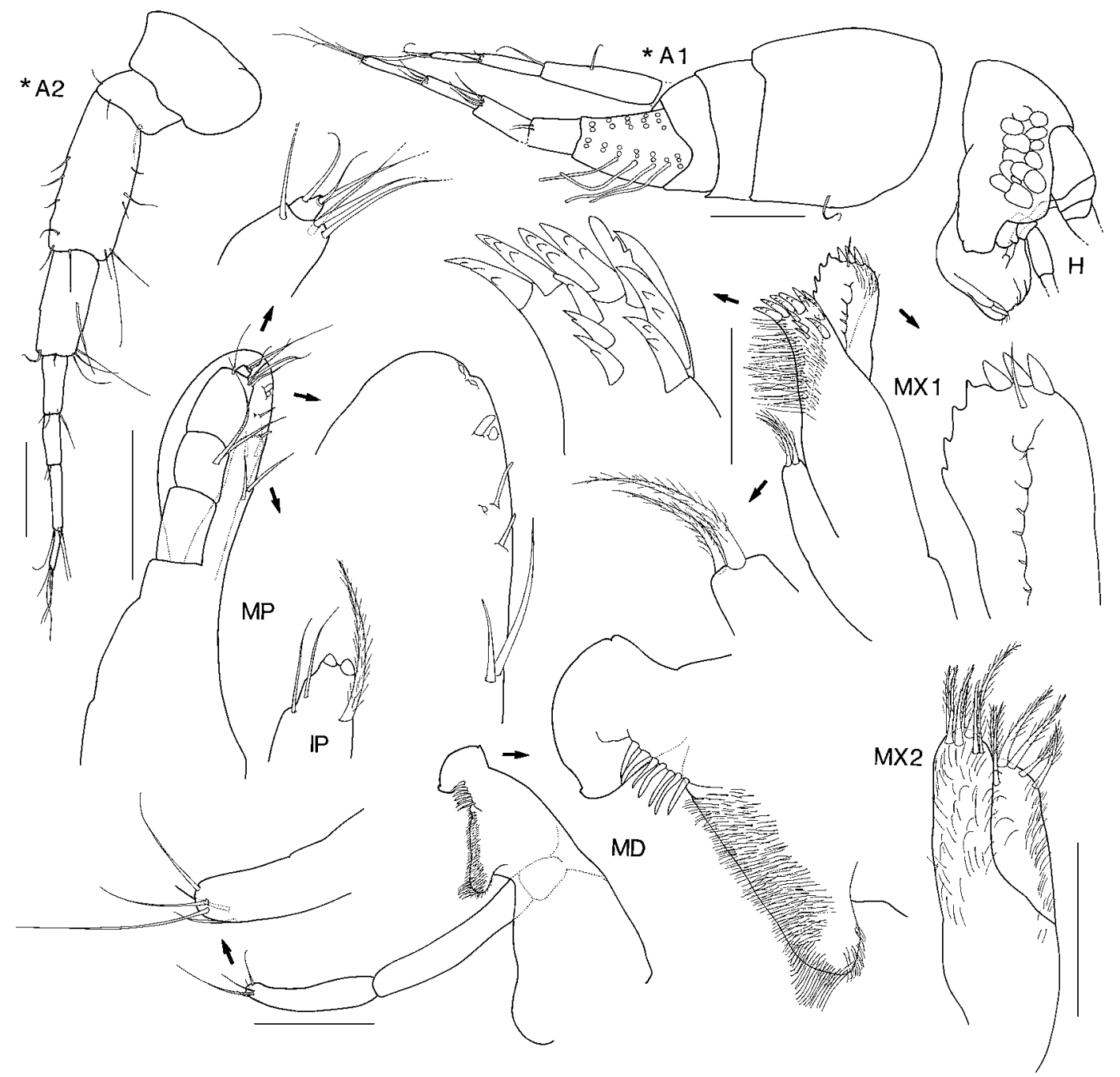

FIGURE 3. Normanion whoi sp. nov. Holotype female, MV J61508. *A1, A2 paratype female, AM P.81162. Scales represent $0.1 \mathrm{~mm}$. 


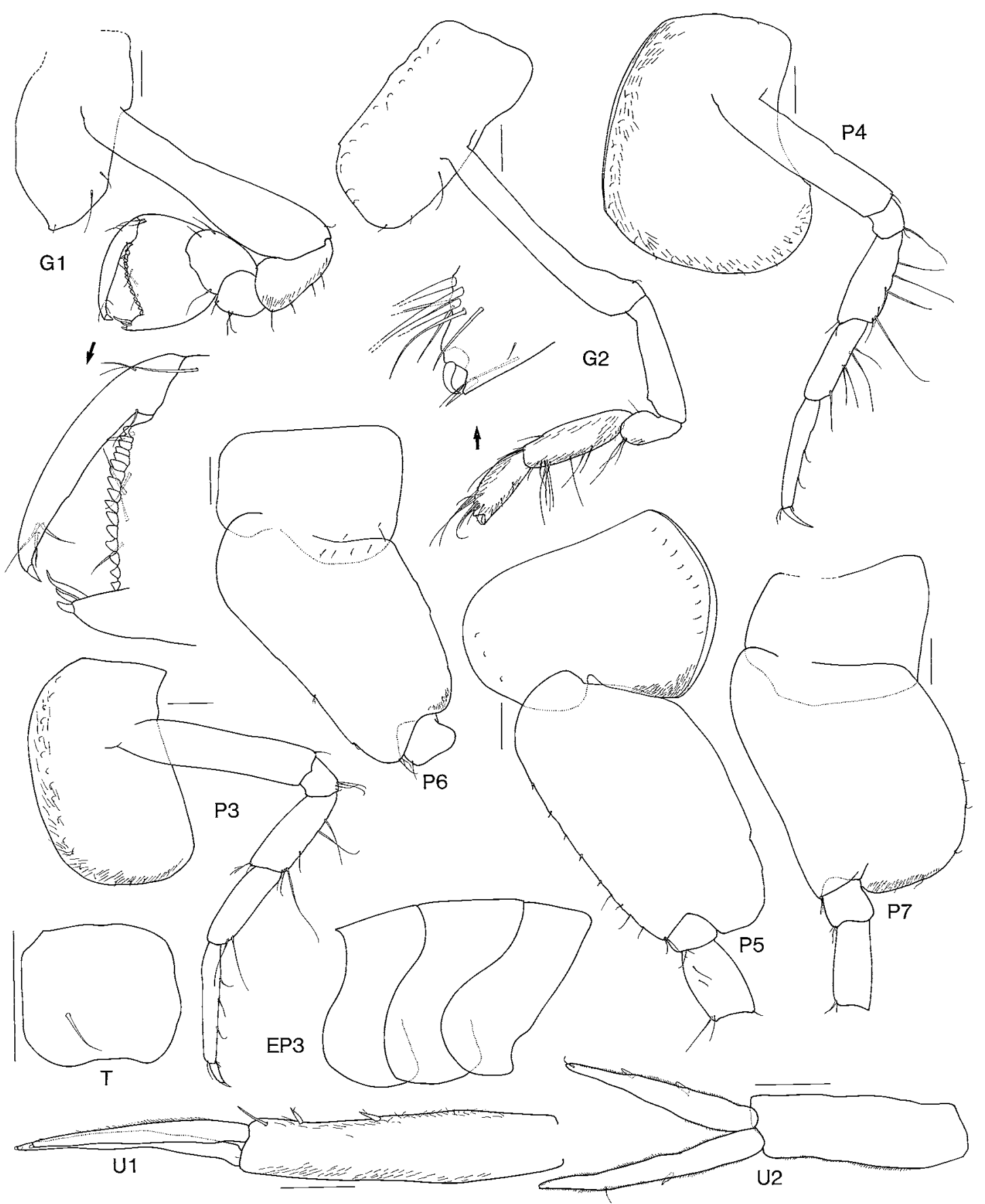

FIGURE 4. Normanion whoi sp. nov. Holotype female, MV 61508. Scales represent $0.1 \mathrm{~mm}$.

\section{Normanion whoi sp. nov.}

(Figs 3, 4)

Type material. HOLOTYPE, female, $3.2 \mathrm{~mm}$, MV J61508, south of Point Hicks, Victoria, Australia, $38^{\circ} 17.70^{\prime} \mathrm{S} 149^{\circ} 11.30^{\prime} \mathrm{E}, 400 \mathrm{~m}$, coarse sand, gravel and mud with many sponges, WHOI epibenthic sled, 24 July 1986, M.F. Gomon et al., RV Franklin, stn SLOPE 40. PARATYPES: 1 female, MV J14615 and 2 females, AM P.81162, same data as holotype; 1 female, MV J61509, off Freycinet Peninsula, Tasmania, Australia, 41 ${ }^{\circ} 58.60^{\prime} \mathrm{S} 148^{\circ} 38.80^{\prime} \mathrm{E}, 500 \mathrm{~m}$, coarse shell, WHOI epibenthic sled, 27 July 1986, M.F. Gomon et al., RV Franklin, stn SLOPE 47.

Type locality. South of Point Hicks, Victoria, Australia, $38^{\circ} 17.70^{\prime} \mathrm{S} 149^{\circ} 11.30^{\prime} \mathrm{E}, 400 \mathrm{~m}$ depth. 
Etymology. The species is named for the epibenthic sled, WHOI, developed at the Woods Hole Oceanographic Institute, Massachusetts, USA.

Diagnostic description. Antenna 1 callynophore present. Eyes present. Mouthpart bundle subconical. Mandible left incisor with strongly convex margin, smooth, right with slightly convex margin, smooth; lacinia mobilis absent; molar present, setose; palp attached midway, article 2 longer than article 3. Maxilla 1 outer plate with 11 setal teeth in an 8/3 crown arrangement, outer row with cusps in 1 row; palp apical margin serrate, with apical robust setae. Maxilliped palp 4-articulate, article 4 vestigial. Gnathopod 1 weakly chelate; ischium long; carpus posterior margin not produced, curved; propodus subovate, proximal margin produced into strong posteroproximal lobe, palm serrate, posterodistal corner produced into a short acute spine with 3 robust setae. Gnathopod 2 minutely chelate; carpus longer than propodus (about 1.5x); palm obtuse. Pereopod 4 coxa posteroproximal excavation large. Pereopods 5-7 basis with smooth posterior margin; [dactylus not known]. Epimeron 3 posterior margin smooth, posteroventral corner broadly rounded. [Uropod 3 unknown.] Telson about as long as broad, entire, distally emarginate, without dorsal robust setae.

Male not known.

Remarks. Unfortunately all specimens lack the distal articles of pereopods 5-7 and uropod 3. Normanion whoi is similar to N. amblyops, N. abyssi and N. hipposideros in having a vestigial article 4 on the maxillipedal palp. It differs from $N$. amblyops and $N$. abyssi in its strongly serrate gnathopod 1 palm and from $N$. hipposideros in having 11 setal teeth on maxilla 1 outer plate, each with only one set of cusps, and a weakly chelate gnathopod 1.

It is interesting to note that the female MV J14615 has the right gnathopod 1 extended and rotated between merus and carpus so that the propodus is inverted as in species of Trischizostoma which are parasitic on fishes. The left gnathopod 1 is tucked in under the coxae and is not inverted.

Distribution. South-eastern Australia; 400-500 m depth.

\section{Podoprionella Sars, 1895}

The genus now contains four species: Podoprionella bulla sp. nov.; P. dagadugaban Lowry \& Stoddart, 1995; P. fissicaudata Ledoyer, 1977 and P. norvegica Sars, 1895. The new species described here is the second record of the genus in the southern hemisphere.

\section{Key to species of Podoprionella}

1. Gnathopod 1 chelate, propodus subrectangular, palm smooth; uropod 3 inner ramus at least half as long as outer ramus

- Gnathopod 1 subchelate, palm almost transverse, propodus subquadrate, palm serrate; uropod 3 inner ramus vestigial.

2. Mandibular palp articles 2 and 3 subequal; telson distally incised P. fissicaudata

- Mandibular palp article 2 much longer than article 3; telson entire P. norvegica

3. Maxilla 1 outer plate setal teeth of outer row with 2 rows of cusps; gnathopod 1 propodus posterodistal corner produced into an acute spine P. dagadugaban

- Maxilla 1 outer plate setal teeth of outer row with 1 row of cusps; gnathopod 1 propodus posterodistal corner produced into a blunt, distally expanded knob-like spine P. bulla

\section{Podoprionella bulla sp. nov.}

(Figs 5-7)

Type material. HOLOTYPE, female, $2.2 \mathrm{~mm}$, MV J61510, off Eden, New South Wales, Australia, $37^{\circ} 0.60$ 'S $150^{\circ} 20.70^{\prime} \mathrm{E}, 363 \mathrm{~m}$, coarse shell, epibenthic sled, 21 July 1986, G.C.B. Poore et al., RV Franklin, stn SLOPE 22. 


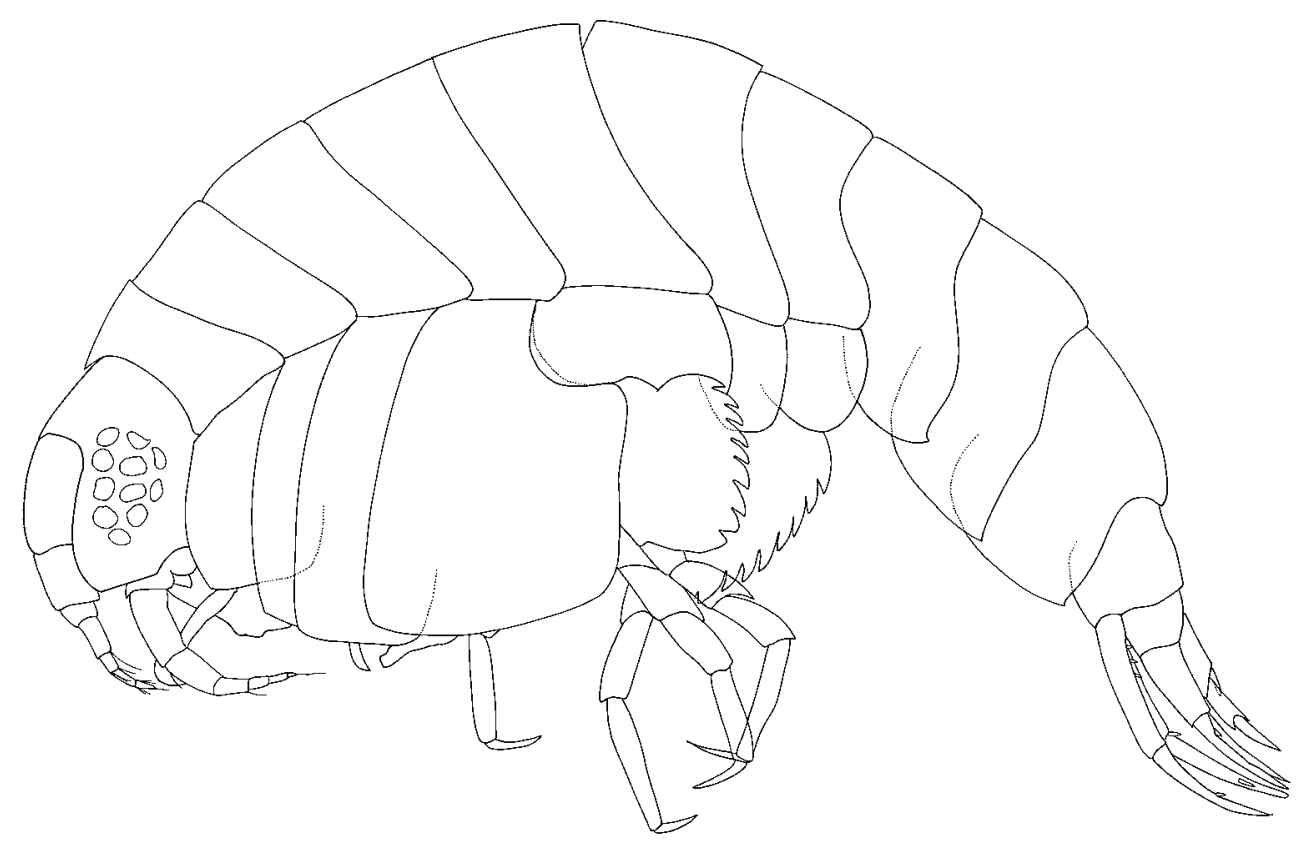

FIGURE 5. Podoprionella bulla sp. nov. Holotype female, MV J61510.

Type locality. Off Eden, New South Wales, Australia, $37^{\circ} 0.60^{\prime} \mathrm{S} 150^{\circ} 20.70^{\prime} \mathrm{E}, 363 \mathrm{~m}$ depth.

Etymology. The species name is from the Latin word for a knob, referring to the irregular spine on the palm of gnathopod 1.

Diagnostic description. Antenna 1 callynophore absent. Eyes present. Mouthpart bundle subconical. Mandible left incisor with straight margin, smooth, right with slightly convex margin, smooth; lacinia mobilis absent; molar absent; palp attached proximally, article 2 longer than article 3. Maxilla 1 outer plate with 7 setal teeth in a 6/1 crown arrangement, outer row with cusps in 1 row; palp apical margin not serrate, without apical setae. Maxilliped palp 3-articulate. Gnathopod 1 subchelate; ischium short; carpus posterior margin produced into broad triangular lobe; propodus subquadrate, proximal margin transverse, palm serrate, posterodistal corner produced into blunt, distally expanded spine, without robust setae. Gnathopod 2 minutely chelate; carpus much longer than propodus (about 2x); palm obtuse. Pereopod 4 coxa posteroproximal excavation small. Pereopods 5-7 basis with strongly serrate posterior margin; dactylus short, slender. Epimeron 3 posterior margin smooth, posteroventral corner acute. Uropod 3 peduncle subequal to outer ramus, with large distoventral spur; inner ramus vestigial; outer ramus 2-articulate; rami without robust setae, without plumose setae. Telson about as long as broad, entire, distally tapered, without dorsal robust setae.

Male not known.

Remarks. Podoprionella bulla is very similar to P. dagadugaban but differs in having no callynophore on antenna 1, only one set of cusps on the setal teeth of maxilla 1 outer plate, an irregular blunt spine on the posterodistal corner of gnathopod 1 propodus, no serrations on the inner margin of gnathopod 1 dactylus and a much deeper posterior lobe on the coxa of pereopods 5 and 6 . Both species differ from the northern hemisphere $P$. fissicaudata and $P$. norvegica in having only two robust setae in the mandible accessory setal row, a transverse serrate palm on gnathopod 1 and a vestigial inner ramus on uropod 3 .

Distribution. South-eastern Australia; 363 m depth. 


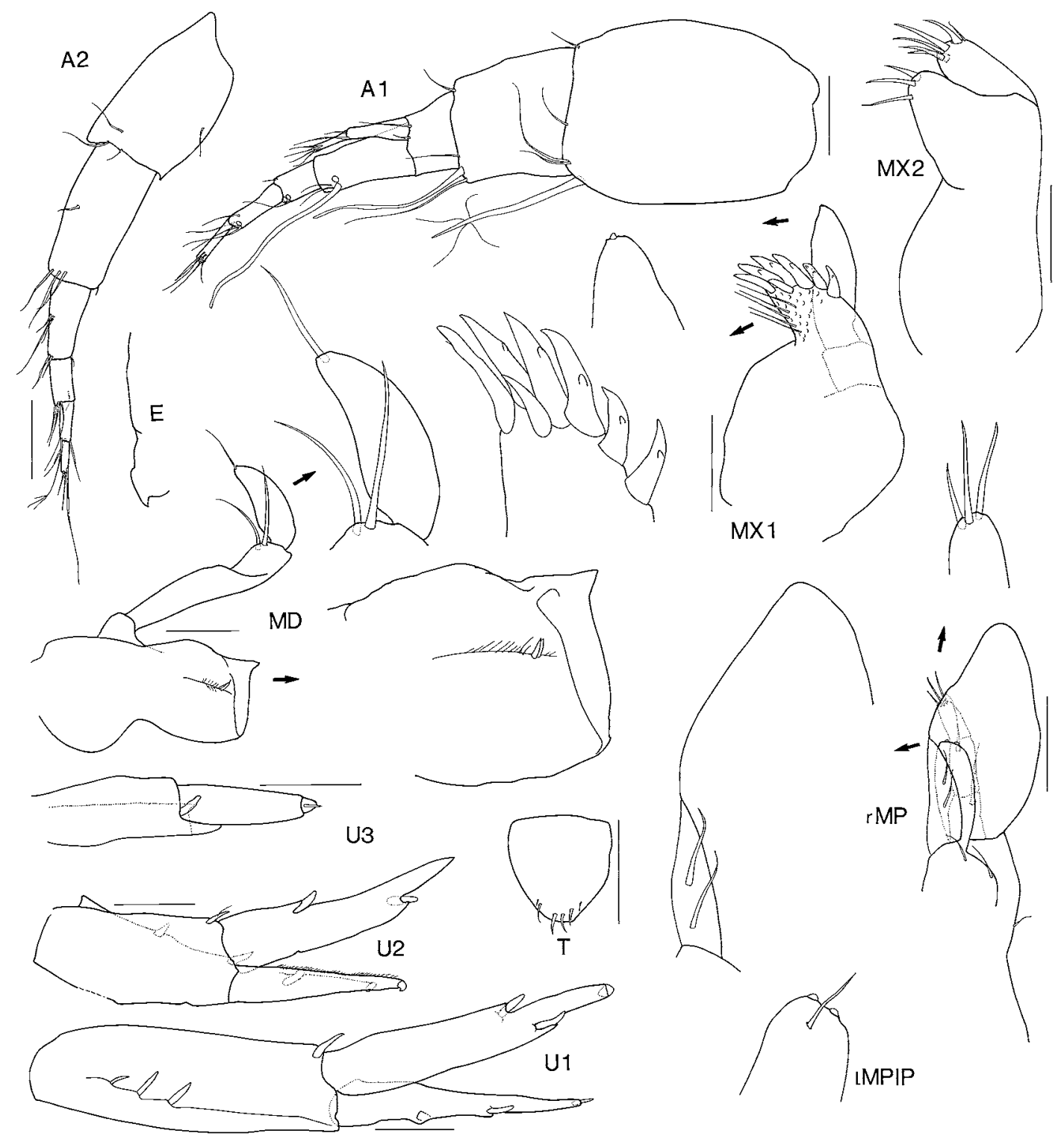

FIGURE 6. Podoprionella bulla sp. nov. Holotype female, MV J61510. Scales represent 0.05 mm.

\section{Podoprionides Walker, 1906}

After more than 100 years of monotypy the genus now contains three species: Podoprionides akantha sp. nov.; P. incerta Walker, 1906 and P. moonamoona sp. nov.

\section{Key to species of Podoprionides}

1. Gnathopod 1 carpus posterior margin produced into a broad triangular lobe; epimeron 3 posteroventral corner quadrate; uropod 3 peduncle subequal to rami P. moonamoona

- Gnathopod 1 carpus posterior margin curved, not produced into a lobe; epimeron 3 posteroventral corner rounded; uropod 3 peduncle shorter than rami

2. Maxilla 1 palp apically serrate, without robust setae; telson deeply cleft (about $80 \%$ ) P. incerta

- Maxilla 1 palp not apically serrate, with small robust setae; telson moderately cleft (about $62 \%$ ) P. akantha 


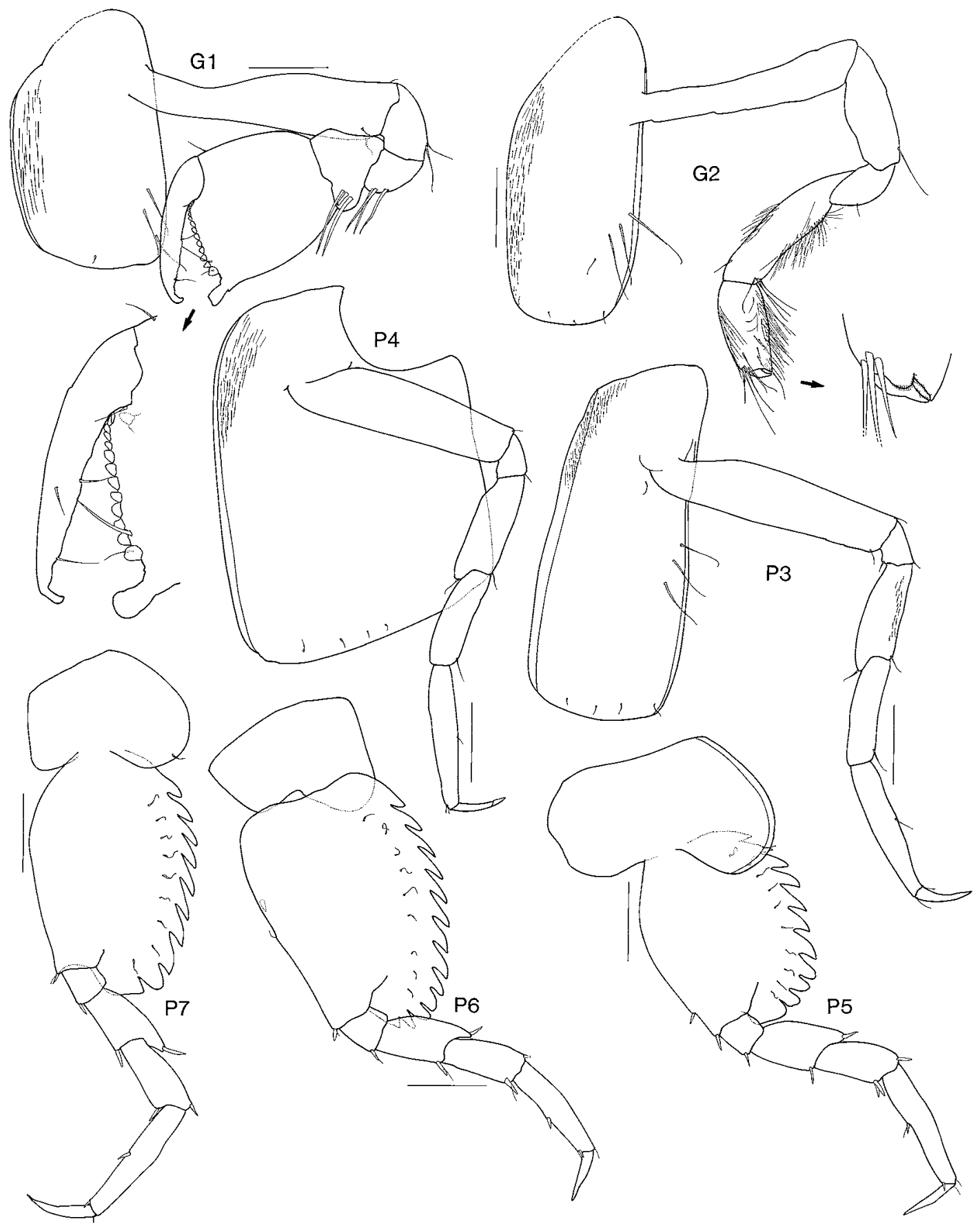

FIGURE 7. Podoprionella bulla sp. nov. Holotype female, MV J61510. Scales represent $0.1 \mathrm{~mm}$.

\section{Podoprionides akantha sp. nov.}

(Figs 8, 9)

Type material. HOLOTYPE, female, $4.2 \mathrm{~mm}$, MV J61511, south of Point Hicks, Victoria, Australia, $38^{\circ} 21.90^{\prime} \mathrm{S} 149^{\circ} 20.00^{\prime} \mathrm{E}, 1000 \mathrm{~m}$, epibenthic sled, 23 July 1986, G.C.B. Poore et al., RV Franklin, stn SLOPE 32.

Type locality. South of Point Hicks, Victoria, Australia, 38²1.90'S $149^{\circ} 20.00^{\prime} \mathrm{E}, 1000 \mathrm{~m}$ depth.

Etymology. The species name is a Greek word for a thorn, referring to the small, thorn-like robust setae on the maxilla 1 palp. 


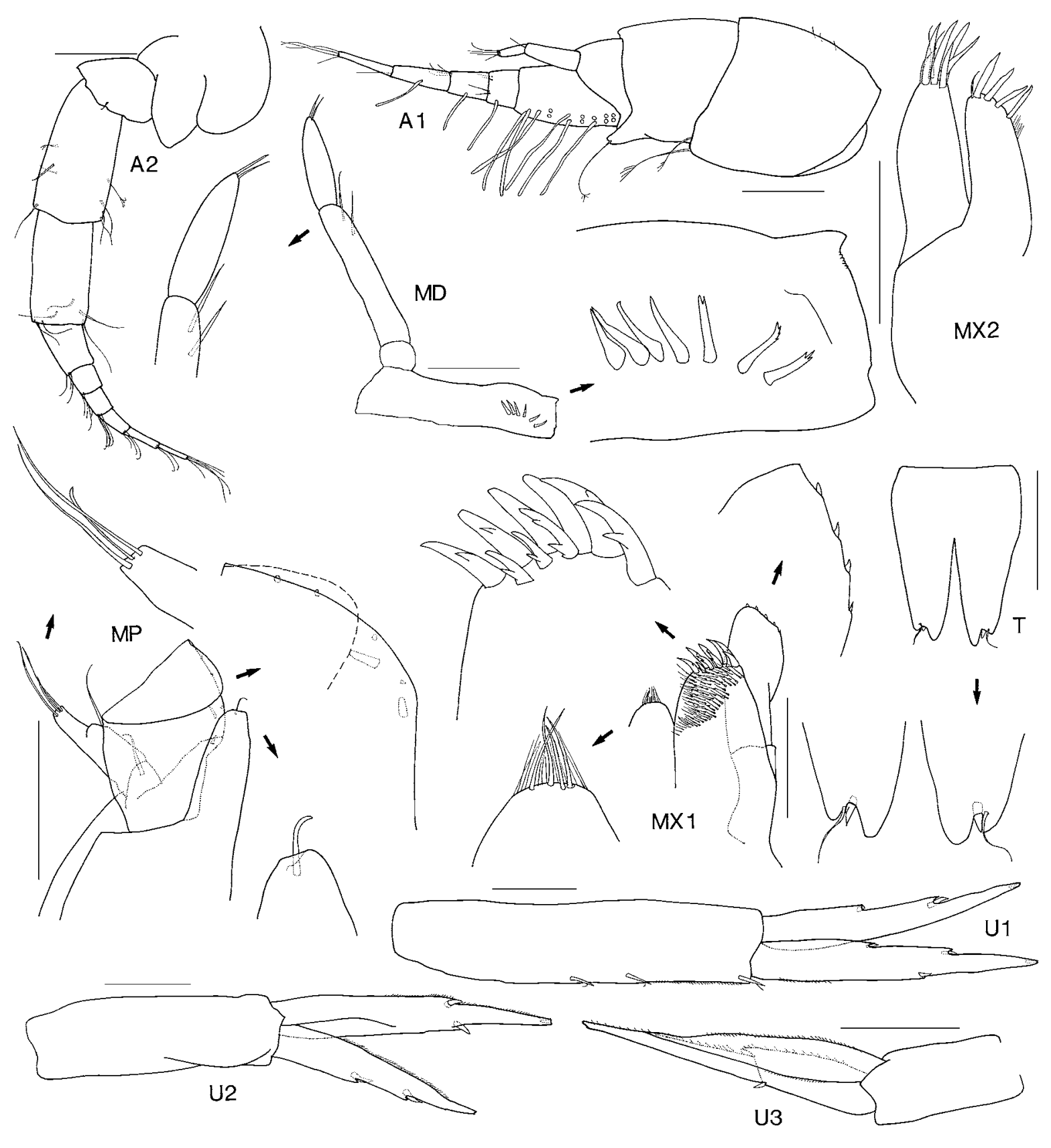

FIGURE 8. Podoprionides akantha sp. nov. Holotype female, MV J61511. Scales represent $0.1 \mathrm{~mm}$.

Diagnostic description. Antenna 1 callynophore present. Eyes apparently absent. Mouthpart bundle subconical. Mandible left incisor with straight margin, minutely serrate, right with slightly convex margin, smooth; lacinia mobilis absent; molar absent; palp attached extremely proximally, article 2 longer than article 3. Maxilla 1 outer plate with 9 setal teeth in a 6/3 crown arrangement, outer row with cusps in 1 row; palp apical margin not serrate, with apical robust setae. Maxilliped palp imperfectly 3-articulate. Gnathopod 1 chelate; ischium short; carpus posterior margin not produced, curved; propodus subrectangular, proximal margin transverse, palm smooth, posterodistal corner produced into long acute spine, without robust setae. Gnathopod 2 minutely subchelate; carpus much longer than propodus (1.7x); palm transverse. Pereopod 4 coxa posteroproximal excavation small. Pereopods 5-7 basis with minutely serrate posterior margin; dactylus long, slender. Epimeron 3 posterior margin smooth, posteroventral corner broadly rounded. Uropod 3 peduncle shorter than rami, without distoventral spur; inner ramus shorter than outer ramus; outer ramus 2- 
articulate, article 2 long; rami without robust setae, without plumose setae. Telson longer than broad, moderately cleft (about $62 \%$ ), without dorsal robust setae.

Male not known.

Remarks. Podoprionides akantha is very similar to $P$. incerta but differs from it in the presence of apical robust setae on the maxilla 1 palp, the weak serrations on the basis of pereopods 5-7 and the less deeply cleft telson. It differs from P. moonamoona as set out under that species.

Distribution. South-eastern Australia; 1000 m depth.

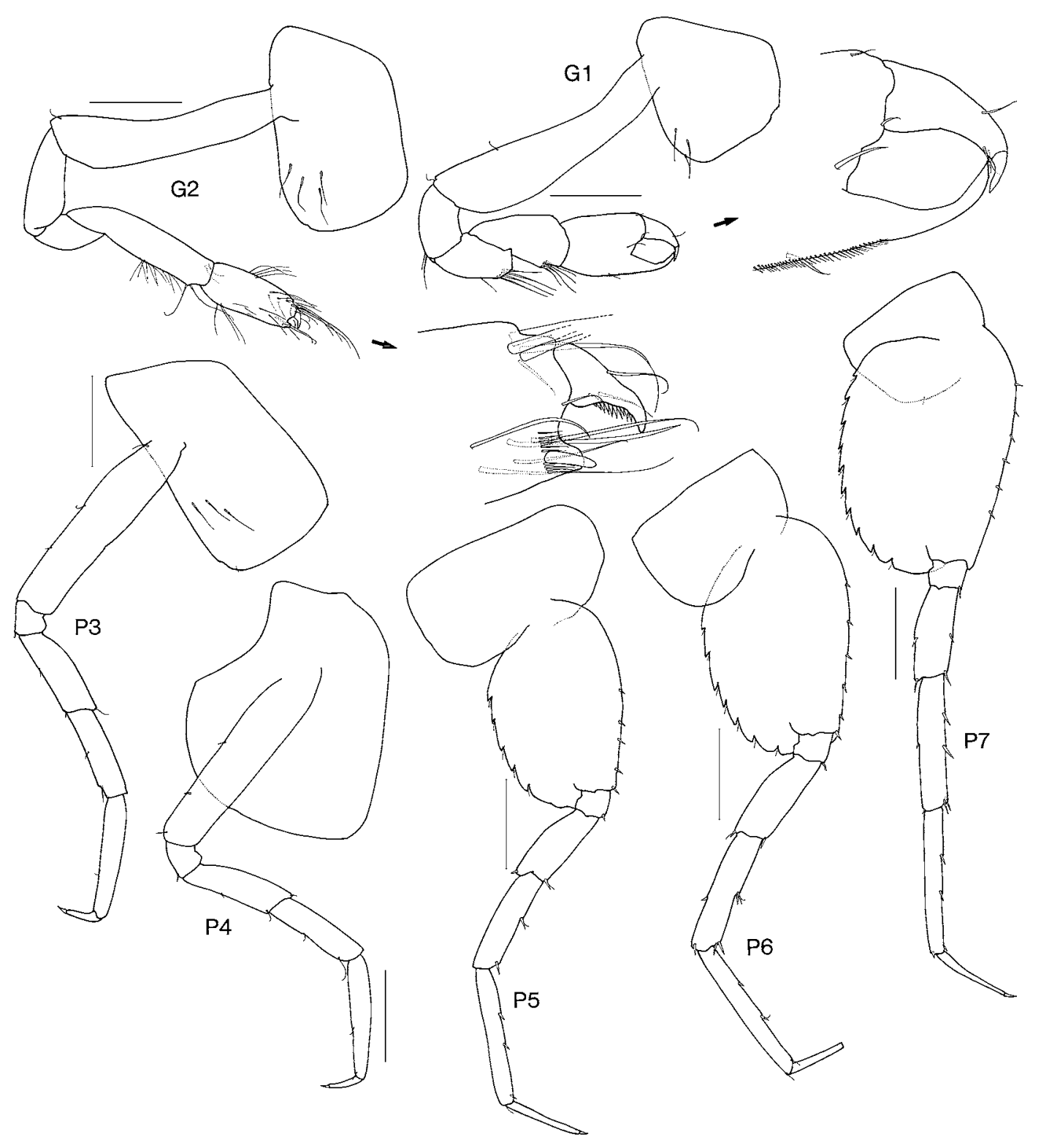

FIGURE 9. Podoprionides akantha sp. nov. Holotype female, MV J61511. Scales represent $0.2 \mathrm{~mm}$.

\section{Podoprionides moonamoona sp. nov.}

(Figs 10-13)

Type material. HOLOTYPE, female, $2.8 \mathrm{~mm}$, AM P.69034, near mouth of Moona Moona Creek, Jervis Bay, New South Wales, Australia, $35^{\circ} 03.5^{\prime} \mathrm{S} 150^{\circ} 41^{\prime} \mathrm{E}, 4.5 \mathrm{~m}$, on test of solitary ascidian Herdmania momus in Ecklonia bed, 17 October 1981, P.B. Berents, stn NSW-235. PARATYPES: female, AM P.69035 and male, 
1.8 mm, AM P.69036 and 44 specimens, AM P.69037, same data as holotype; 2 specimens, AM P.69038, same data, 19 December 1981, stn NSW-236; 2 specimens, AM P.69039, same data, 22 May 1982, stn NSW241.

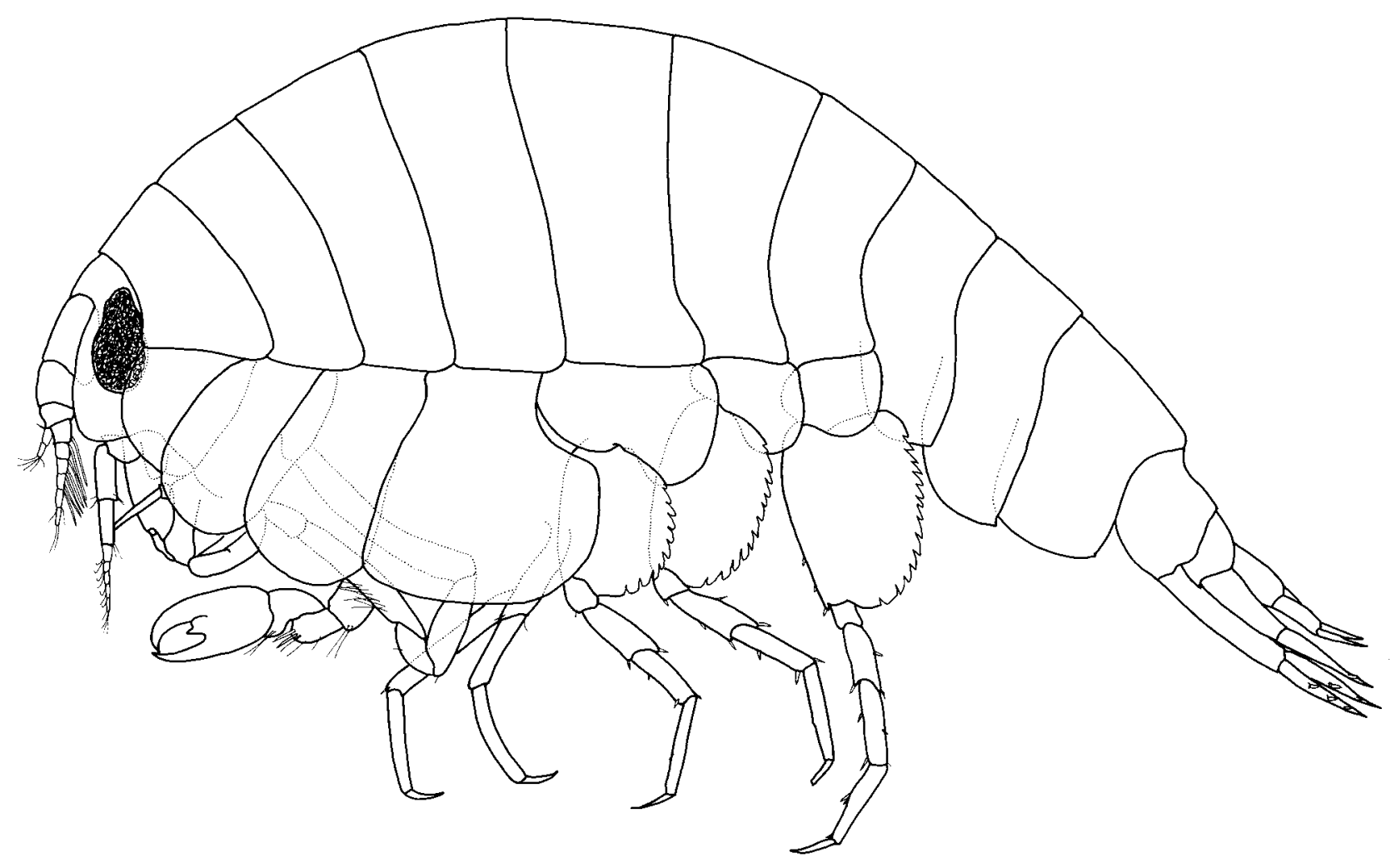

FIGURE 10. Podoprionides moonamoona sp. nov. Holotype female, AM P.69034.

Type locality. Jervis Bay, New South Wales, Australia, $35^{\circ} 03.5^{\prime} \mathrm{S} 150^{\circ} 41^{\prime} \mathrm{E}, 4.5 \mathrm{~m}$ depth.

Etymology. The species name refers to the type locality.

Diagnostic description. Antenna 1 callynophore absent; calceoli absent in male. Eyes present. Mouthpart bundle subconical. Mandible left incisor with straight margin, minutely serrate, right with strongly convex margin, smooth; lacinia mobilis absent; molar absent; palp attached extremely proximally, article 2 longer than article 3. Maxilla 1 outer plate with 9 setal teeth in a 6/3 crown arrangement, outer row with cusps in 1 row; palp apical margin serrate, without apical setae. Maxilliped palp 3-articulate. Gnathopod 1 chelate; ischium short; carpus posterior margin produced into broad triangular lobe; propodus subquadrate, proximal margin produced into strong posteroproximal lobe, palm smooth with a small central bump, posterodistal corner produced into long acute spine, without robust setae. Gnathopod 2 minutely subchelate; carpus much longer than propodus (about $2 \mathrm{x}$ ); palm transverse. Pereopod 4 coxa posteroproximal excavation small. Pereopods 5-7 basis with strongly serrate posterior margin; dactylus short, slender. Epimeron 3 posterior margin smooth, posteroventral corner rounded. Uropod 3 peduncle subequal to inner ramus, without distoventral spur; inner ramus shorter than outer ramus; outer ramus 2-articulate, article 2 long; rami without robust setae, without plumose setae. Telson about as long as broad, moderately cleft (about 56\%), without dorsal robust setae.

Male. Same as female except: Gnathopod 1 palm with large irregular central protrusion; dactylus with irregular protrusion on inner margin. Pereopod 7 merus anterodistal corner with single very large, distally complex robust seta.

Remarks. Podoprionides moonamoona differs from both P. incerta and P. akantha in the absence of a callynophore, the ornamentation of gnathopod 1 palm, and the peduncle of uropod 3 subequal to the rami, which is based on our examination of the orginal type of $P$. incerta.

Distribution. Eastern Australia; $4.5 \mathrm{~m}$ depth 


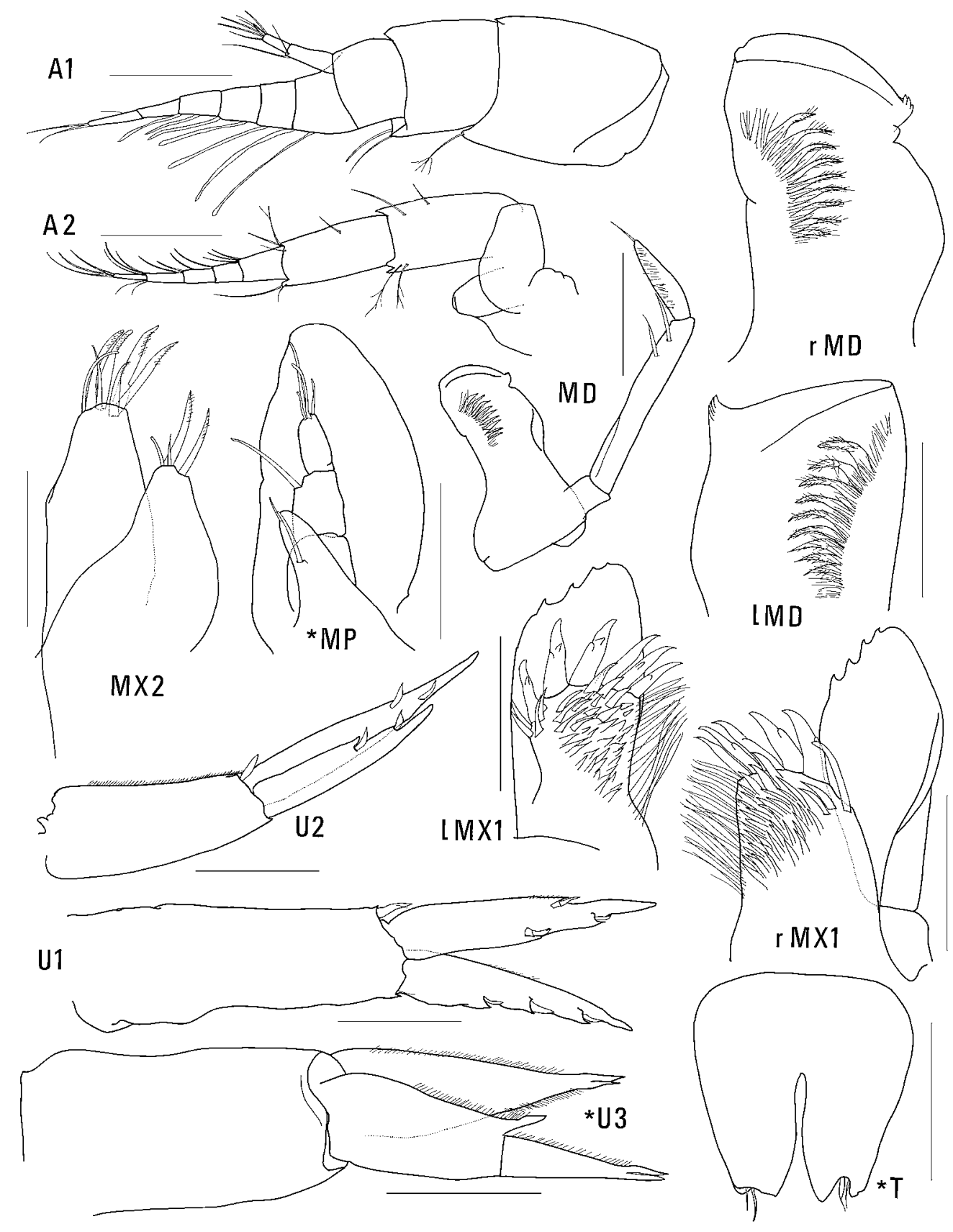

FIGURE 11. Podoprionides moonamoona sp. nov. Holotype female, AM P.69034; *MP, U3 and T, paratype female, AM P.69035. Scales for A1, A2, MD, U1, U2 represent $0.1 \mathrm{~mm}$; remainder represent $0.05 \mathrm{~mm}$.

\section{Acknowledgements}

We thank Gary Poore (Museum Victoria), for the loan of material; Rachael Peart and Kate Dempsey for illustrations; Roger Springthorpe and Lauren Hughes (Australian Museum) for producing our plates. This work was partially supported by a grant from ABRS which allowed HES to participate in the project. 


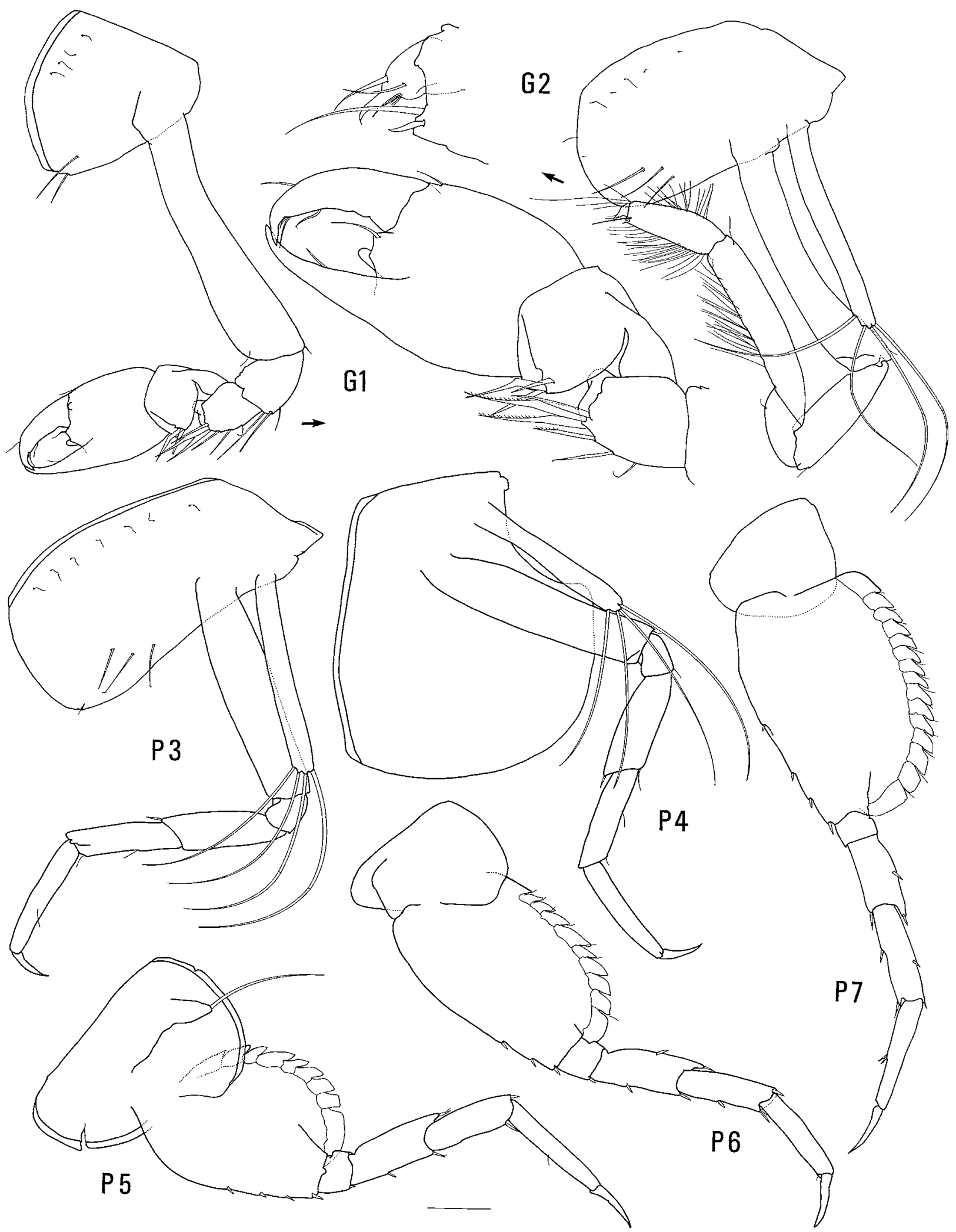

FIGURE 12. Podoprionides moonamoona sp. nov. Holotype female, AM P.69034. Scale represents $0.1 \mathrm{~mm}$. 


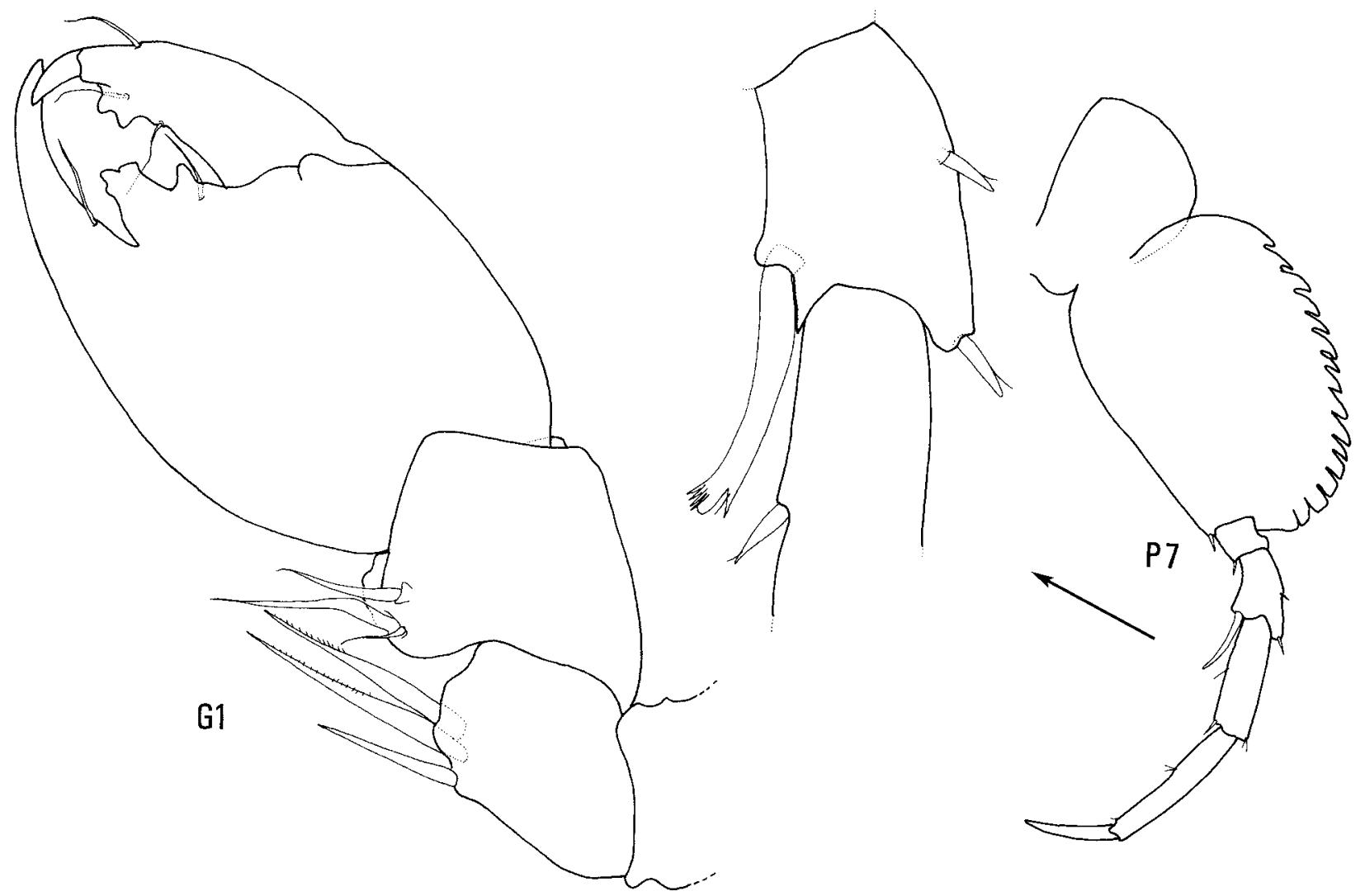

FIGURE 13. Podoprionides moonamoona sp. nov. Paratype male, AM P.69036.

\section{References}

Bate, C.S. \& Westwood, J.O., Eds. (1868) A History of the British Sessile-eyed Crustacea. London, John Van Voorst.

Bonnier J. (1893) Les amphipodes du Boulonnais (1). Bulletin scientifique de la France et de la Belgique, 24, 161-207, pls 3-8.

Bousfield, E.L. (1987) Amphipod parasites of fishes of Canada. Canadian Bulletin of Fisheries and Aquatic Sciences, 217, 1-37.

Chevreux, E. (1903) Campagnes scientifiques de S.A. le Prince Albert $\mathrm{I}^{\mathrm{er}}$ de Monaco. Note préliminaire sur les amphipodes de la famille des Lysianassidae recueillis par la Princesse Alice dans les eaux profondes de l'Atlantique et de la Méditerranée. Bulletin de la Société Zoologique de France, 28, 81-97.

Dallwitz, M.J. (2005) Overview of the DELTA System. http://delta-intkey.com/www/overview.htm. (8/9/2007).

Diviacco, G. \& Vader, W. (1988) The genus Normanion Bonnier in the Mediterranean Sea, with the description of two new species (Amphipoda, Lysianassoidea). Crustaceana, 54(2), 117-128.

Hurley, D.E. (1963) Amphipoda of the family Lysianassidae from the west coast of North and Central America. Allan Hancock Foundation Publications, Occasional Paper, 25, 1-160.

Kilgallen, N.M., Myers, A.A. \& McGrath, D. (2006) A revision of the North Atlantic amphipod genus Normanion (Crustacea: Amphipoda: Lysianassoidea). Zootaxa, 1363, 1-21.

Ledoyer, M. (1977) Contribution à l'étude de l'ecologie de la faune vagile profonde de la Méditerranée nord occidentale I. Les gammariens (Crustacea, Amphipoda). Bollettino del Museo Civico di Storia Naturale di Verona, 4, 321-421.

Lincoln, R. (1979) British Marine Amphipoda: Gammaridea. British Museum of Natural History, i-v, 1-658.

Lowry, J.K. \& Myers, A.A. (2009) Foreword, pp 17-108. In: Lowry, J.K. \& Myers, A.A. (Eds) (2009) Benthic Amphipoda (Crustacea: Peracarida) of the Great Barrier Reef, Australia. Zootaxa, 2260, 1-930.

Lowry, J.K. \& Smith, S.D.A. (2003) Invertebrate Scavenging Guilds along the Continental Shelf and Slope of Eastern Australia - General Description. Australian Museum, Sydney, 59 pp.

Lowry, J.K. \& Stoddart, H.E. (1995) The Amphipoda (Crustacea) of Madang Lagoon: Lysianassidae, Opisidae, Uristidae, Wandinidae and Stegocephalidae. Records of the Australian Museum, Supplement, 22, 97-174.

Sars, G.O. (1895) An Account of the Crustacea of Norway with Short Descriptions and Figures of all the Species. Vol. I. 
Amphipoda. Parts 31, 32, Appendix. Alb. Cammermeyer, Christiana. pp. 673-711, suppl. pls. 1-8.

Vader, W. \& Romppainen, K. (1985) Notes on Norwegian marine Amphipoda. 10. Scavengers and fish associates. Fauna Norvegica, Series A, 6, 3-8.

Walker, A.O. (1906) Preliminary descriptions of new species of Amphipoda from the 'Discovery' Antarctic Expedition, 1902-1904. Annals and Magazine of Natural History, Series 7, 17, 452-458. 